Eugenio Gastiazoro: del MLN al PCR, de la Economía a la Historia (1965-1989)

Matías J. Rubio

Anuario № 31 / ISSN 1853-8835 / 2019

http://anuariodehistoria.unr.edu.ar/ojs/index.php/Anuario/index

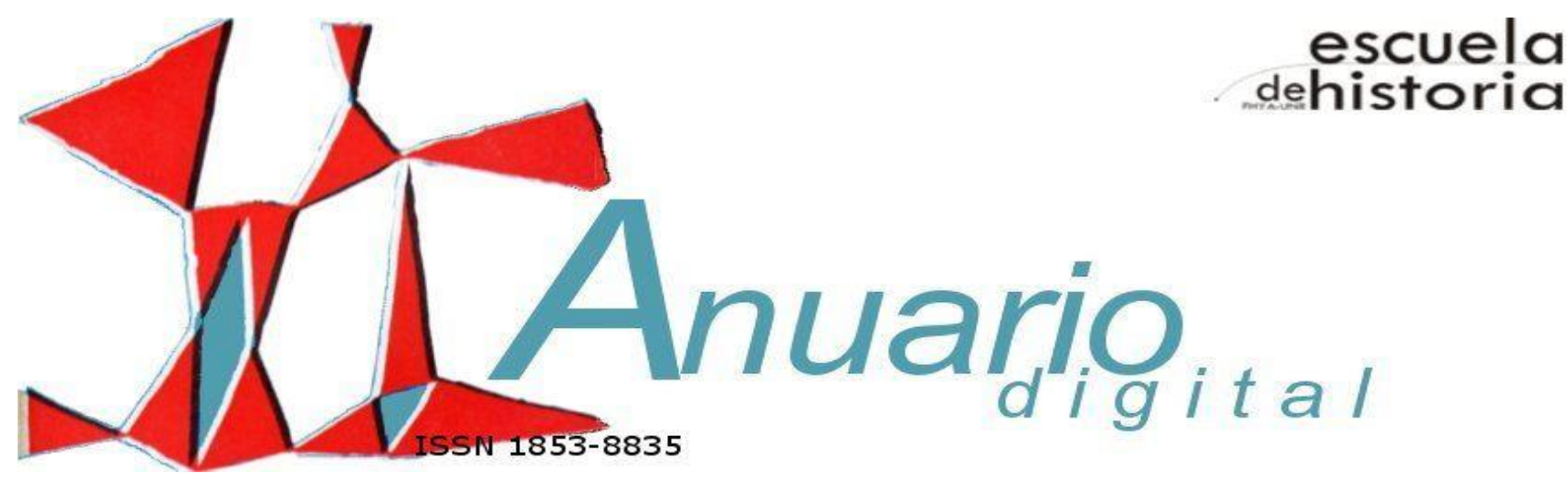

Eugenio Gastiazoro: del MLN al PCR, de la Economía a la Historia (1965-1989)

Eugenio Gastiazoro: from National Liberation Movement to Revolutionary Communist Party, from Economy to History (1965-1989)

MATIAS J. RUBIO

Universidad Nacional de Luján, (Argentina) rubiomatias08@hotmail.com.ar

RESUMEN

Este articulo aborda la trayectoria política e intelectual de Eugenio Gastiazoro, entre 1939 y 1989. Haciendo énfasis en el periodo que va desde su participación en el Movimiento de Liberación Nacional (1965-1969) hasta las primeras dos décadas de militancia en el Partico Comunista Revolucionario (1969-1989), analizamos sus elaboraciones intelectuales con el objetivo de reconocer las líneas generales de sus intervenciones políticas, de identificar las posiciones por él asumidas, el carácter de sus producciones intelectuales y los roles ocupados en términos organizativos.

Palabras clave: Eugenio Gastiazoro; Movimiento de Liberación Nacional; Partido Comunista Revolucionario; izquierda; intelectuales.

ABSTRACT

Esta obra está sujeta a la Licencia Reconocimiento-NoComercial-CompartirIgual 4.0 Internacional de Creative Commons. http://creativecommons.org/licenses/by-nc-sa/4.0/

(cc) EY-NC-SA 


\section{Eugenio Gastiazoro: del MLN al PCR, de la Economía a la Historia (1965-1989)}

This article addresses the political and intellectual career of Eugenio Gastiazoro between 1939 and 1989. Placing an emphasis on the period since his involvement in the National Liberation Movement (1965-1969) until the first two decades of militancy in the Revolutionary Communist Party (1969-1989), his intellectual developments are analyzed with the objective of recognizing the fundamental features of his political interventions, identifying his taken positions, the character of his intellectual outcomes and the roles taken regarding organizational terms.

Keywords: Eugenio Gastiazoro; National Liberation Movement; Revolutionary Communist Party; left wing; intellectuals.

En este trabajo -que forma parte de una investigación, sobre la historiografía del Partido Comunista Revolucionario entre 1967 y 1987, que lo excede ${ }^{1}$ - abordamos la trayectoria política e intelectual de Eugenio Gastiazoro, entre las décadas de 1960 y 1980. Es decir, desde su participación en el Movimiento de Liberación Nacional (MLN) hasta las primeras décadas de militancia en el PCR. Nuestra intención es indagar en las posiciones por él asumidas con el objetivo de reconocer las líneas generales de sus intervenciones políticas, el carácter de sus producciones intelectuales y los roles ocupados en términos organizativos. Con ello apuntamos a realizar una contribución en dos aspectos: su trayectoria personal y los vínculos con las organizaciones políticas involucradas. Para ello trabajaremos centralmente con entrevistas, sus producciones escritas $^{2}$, documentos de las fuerzas políticas aludidas y la producción historiográfica existente sobre ellas. Por cuestiones de espacio, presentaremos una visión sintética del recorrido político e intelectual y nos detendremos en la explicación de las transformaciones producidas en su recorrido político y en sus elaboraciones intelectuales a lo largo de las décadas del '60, '70 y '80: sus inicios en la militancia en el MLN, su paso al PCR y, finalmente, su desplazamiento desde la Economía, como disciplina, a la Historia, como instrumento de explicación de determinados fenómenos.

\footnotetext{
${ }^{1}$ Esta área de estudios, en que inscribimos nuestra investigación, se ha denominado como historiografías militantes. Lo especifico de esta forma de escribir la historia es su relación con la cuestión política; es decir, en estos casos la operación historiográfica es subordinada a la política mediata e inmediata. Por ello se ha afirmado que, en contraste con la historiografía académica, sus ritmos son diferentes ya que suele ser escrita, con frecuencia, para que se la consuma en el mismo momento de su producción. El desarrollo y las características de estas experiencias, dada la relevancia otorgada a la intervención política, se encuentran en estrecha relación con su contexto histórico, entendiendo este último como la forma que toma la intervención política, en un momento dado, por el actor/autor. Al respecto véase: Omar Acha (2009), Fernando Devoto y Nora Pagano (2004; 2009) y Daniel Campione (2002). En el caso de la historiografía producida por el PCR, salvo por el tratamiento de carácter general realizado por Omar Acha (2009, pp. 195-201) y nuestros avances (Rubio, 2018a; 2018b;2018c; 2017;2015), no contamos con trabajos que aborden la cuestión.

${ }^{2}$ En este punto aclaramos que nos centraremos en sus artículos aparecidos en revistas y sus libros, dejando fuera los publicados en las prensas partidarias.
}

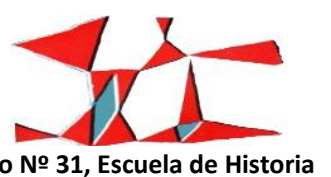


MATIAS J. RUBIO

Para la construcción de nuestro análisis prestamos particular atención a los aspectos biográficos, a los coyunturales (en tanto elementos determinantes de la forma que fue tomando la producción política e intelectual del autor), los espacios y momentos de formación, el universo familiar y laboral, los viajes y las tramas de amigos (Pasquale y Summo, 2015, pp. 11-19). Para pensar la cuestión intelectual en los años sesenta y setenta y su tensión con lo político, si bien existen trabajos canónicos que abordaron aquel proceso de radicalización intelectual y propusieron una periodización desde una perspectiva general (Sigal, 1991; Gilman, 2003; De Diego, 2003), retomamos los señalamientos realizados por Beatriz Sarlo (2007, p. 143). Según esta última, en aquellas décadas, la cuestión intelectual se habría resuelto/disuelto en la cuestión política, produciéndose la emergencia de una nueva forma de cultura. Sobre la base de esta caracterización general, podemos permitirnos plantear que en la formación y trayectoria de E. Gastiazoro como político e intelectual fue determinante el proceso de vinculación entre actividad política e intelectual, de la que pretendemos dar cuenta.

\section{Del campo a la ciudad (1939-1969)}

E. Gastiazoro nació el 20 de diciembre de 1939 en Villa Urquiza, provincia de Entre Ríos, en el seno de una familia inmigrante, vascos, suizos y alemanes, que se había asentado en la zona en la segunda mitad del siglo XIX y vivía de la producción agropecuaria. Producto de las políticas crediticias del peronismo, sus padres pudieron adquirir unas cuantas hectáreas y, por tal motivo, en el núcleo familiar se vio con cierta simpatía al primer gobierno de Juan D. Perón. La posición social de la familia es catalogada por Gastiazoro, en la actualidad, como de "campesino medio". En su lenguaje y el del PCR (al que adhirió en 1969), este sector social estaría comprendido por aquellos cuyos ingresos principales vienen del trabajo propio y el de su familia. Por lo general viven en su propia tierra. Algunos contratan mano de obra asalariada pero la plusvalía que obtienen representa una parte menor del ingreso que proviene de su propio trabajo. (...) Su conformación como clase, por lo general, proviene de una o dos generaciones anteriores y por lo tanto se agudiza y actualiza el problema de la tierra para sus hijos (Álvarez, 1979, p. 46)

La visión retrospectiva, coloca a sus padres dentro de esta clasificación social derivada de los parámetros analíticos del maoísmo. A su vez, en términos políticos, el mismo análisis sentenciaba que "dadas sus contradicciones objetivas con los terratenientes, contra quienes han tenido que luchar a lo largo de

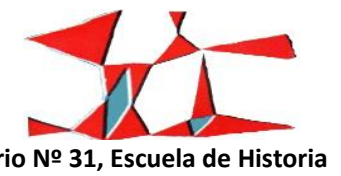




\section{Eugenio Gastiazoro: del MLN al PCR, de la Economía a la Historia (1965-1989)}

muchos años para alcanzar su posición actual, es posible ganar a la gran mayoría de ellos para la Revolución" (Álvarez, 1979, pp. 46.47).

En 1946 ingresó al Colegio de las Hermanas Franciscanas de Gante donde pudo hacer toda su formación primaria, aunque previamente había aprendido a leer y escribir en su casa. Allí concurrió, cada día, luego de atravesar unos $5 \mathrm{~km}$ a caballo. Al terminar la primaria, se trasladó a la ciudad de Paraná, ubicada a unos $40 \mathrm{~km}$ al sur, para estudiar perito mercantil en el Colegio Nacional. Todo este desplazamiento fue "parte del esfuerzo de mi vieja, que llegaba a criar chanchitos y gallinas, como dos mil tenía. Con el cual nos hizo estudiar a los tres más grandes. A la más chica casi la hace monja, pero a los tres más grandes nos bancó el estudio" ${ }^{3}$.

En 1958 ingresó a la Universidad Nacional del Litoral (UNL) para estudiar la carrera de Contador Público, realizando en 1960 el servicio militar. Aún viviendo en Paraná, viajaba periódicamente a la ciudad de Santa Fe para el cursado de la carrera. En esta última, tomo contacto por primera vez con las ideas políticas, aunque no militó en una organización mientras estudió. Ese momento coincidió con el ascenso de Arturo Frondizi a la presidencia y el auge de las ideas desarrollistas en el ámbito intelectual, con las que no acordó. Al menos en su visión retrospectiva, sostiene que

yo ahí me entero, por primera vez, que no existen los campesinos. Lo que propone el desarrollismo es que los campesinos ya no eran más campesinos, ahora teníamos capitalismo, empresarios del campo. (...) Entonces ahí caigo en la razón que eso ahí no existía más. Antes por lo menos en el Paraná era el rusito del campo $^{4}$

Aunque se habría "Ilevado mal" desde un primer momento, veremos que recién años después dedicará algunos trabajos a la crítica del desarrollismo.

En la universidad conoció la teoría marxista a partir de los "manuales de ciencia de la URSS" y entró en contacto con gente del MLN, al que se afilió en 1963 y al que ingresará definitivamente en 1966. El elemento determinante para la construcción del vínculo sería, en su consideración, el apoyo brindado por el MLN al peronismo en las elecciones provinciales de 1962, unos días antes que estalle el golpe contra el gobierno de los radicales intransigentes. La consecuencia de este primer acercamiento fue su integración a un "equipo de estudios" formado por miembros del MLN, entre los que estaban "Susana Fiorito, (...) Juan

\footnotetext{
${ }^{3}$ Entrevistas a Eugenio Gastiazoro, realizadas por el autor, entre abril y noviembre de 2018.

${ }^{4}$ Ídem.

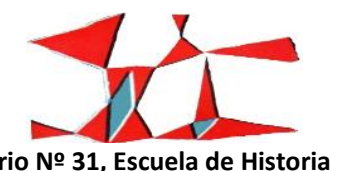


MATIAS J. RUBIO

Carlos Conti y Leopoldo N. Weissmann", dedicado a investigar "una serie de temas encarados desde la perspectiva nacionalista, revolucionaria y socialista" y del que fue producto la publicación del folleto titulado Ferrocarriles: ¿reestructuración o entrega? (1965). Allí, luego de un análisis histórico del sector y del plan de reestructuración planteado por el gobierno, se propuso reorganizar la red ferroviaria sobre la base de un proyecto que contemplara los "objetivos nacionales" en pos de lograr "la unificación total del mercado nacional, el estímulo al desarrollo del interior (...) [y] el establecimiento de un poderoso punto de apoyo a la industria nacional" (Gastiazoro y Fiorito, 1965, s/p).

Luego de haber finalizado la carrera de grado, en 1961 se mudó a Rosario y cursó, entre 1963 y 1964 , el Doctorado en Ciencias Económicas de la misma universidad. Mientras trabajaba como profesor de Contabilidad en el Comercial de San Gregorio y escribía su tesis doctoral, se postuló a una beca para estudiar en Estados Unidos, "un programa de desarrollo económico que hacia la Universidad de Vanderbilt, a través de ARICANA, que era Asociación Rosarina de Intercambio Cultural argentino-norteamericano". Finalmente, la ganó, estudió intensivamente inglés y en 1965 vivió en EE. UU. mientras estudiaba. ${ }^{5}$

Con una beca que constaba de 150 dólares mensuales, además de los pasajes de ida y vuelta, vivió en Nashville, Tennessee, mientras cursaba. En la actualidad considera que "era un curso progresista, destinado al tercer mundo. Había asiáticos, latinoamericanos, turcos, griegos. Lo que no había eran negros, africanos. Y se enseñaba un marxismo desarrollista, un marxismo revisionista. Una mezcla de... sería la aprobación del desarrollo sin romper el capitalismo digamos". Entre el contingente asiático, recuerda, estaba Muhammad Yunus: economista bengalí, condecorado con el premio nobel de la paz en 2006.

En Vanderbilt, para obtener el título de "master", presentó una tesis, "que no tiene nada que ver con lo que hacia acá [Argentina]". Allí escribió un trabajo en torno a "la controversia en los términos de intercambio". Por recomendación de sus profesores, antes de finalizar su estadía en EEUU, se reunió en Nueva York con gente de la Corning Glass, quienes le propusieron trabajar con ellos en Argentina ${ }^{6}$. La propuesta fue rechazada y, luego de viajar por el sur norteamericano y parte de México con sus compañeros de cursada,

\footnotetext{
${ }^{5}$ Aunque aún no ocupaba un lugar de dirección en el MLN, la respuesta de la organización respecto a lo oportuno de abandonar el país fue importante en la decisión que acabo tomando. Al respecto señala que "consulte con el MLN si convenía que me fuera o no, estaba el gobierno de Illia. Las manifestaciones por la República Dominicana. Estaba bastante tranquilo este país y bueno razonablemente no te vas a quedar, me iba a ir a estudiar un año y volver. No me dijeron, pero yo no iba a quedarme más tiempo." Entrevistas a Eugenio Gastiazoro, op. cit..

6 "Me invitan de la Corning Glass para que vaya en las vacaciones de invierno, en navidad, para que vaya a Nueva York a la Corning Glass. Tenía la oportunidad de entrevistarme con su representante en Argentina, que se yo. Yo fui, me presentaron el departamento de Latinoamérica, estaba Don Emilio van Peborgh [quien sería Ministro de Defensa Nacional de la dictadura de Onganía entre 1967 y 1969] que era el hombre, nuestro hombre, en Rigolleau. La Corning Glass se había adueñado de Rigolleau. Rigolleau pasó a ser yankee no sé en qué año". Idem.
}

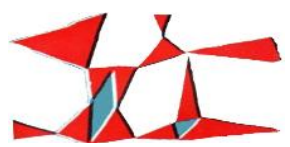

Anuario № 31, Escuela de Historia 


\section{Eugenio Gastiazoro: del MLN al PCR, de la Economía a la Historia (1965-1989)}

regresó a Argentina en "septiembre, octubre del '66". En la ciudad de Rosario se encontró con que el golpe del militar Juan Carlos Ongania había desplazado a Samuel Gorban ${ }^{7}$, docente y decano de la Facultad de Ciencias Económicas de la UNL (1955-1966) y director de su tesis doctoral sobre el Instituto Argentino de Promoción del Intercambio (IAPI).

En ese momento ingresó orgánicamente a militar en el MLN y se trasladó a Buenos Aires, integrándose al grupo que se encargaba de elaborar y publicar el periódico Liberación ${ }^{8}$. Ante la imposibilidad de continuar la vida académica, por la irrupción del onganiato, buscó trabajo en el ámbito privado. Así, casi inmediatamente, logró ingresar a la petrolera ESSO que había publicado un anuncio donde "pedían asesor, economistas para el departamento de economía". Hasta fines de 1967 trabajó allí, cuando "amablemente" lo exhortaron a irse por una cuestión ideológica. Al parecer, había llegado a manos de los gerentes el folleto sobre los ferrocarriles escrito en 1965 con Susana Fiorito y su prédica antiimperialista en el periódico de la organización. Luego, por un contacto en común con Juan Vital Sourrouille, a los pocos meses, ya en 1968, ingresó a trabajar en el Consejo Nacional de Desarrollo (CONADE), más precisamente "en el área destinada al estudio y análisis del comercio exterior".

EI MLN, fue un agrupamiento impulsado por un grupo de intelectuales, ligados al radicalismo, que habían hecho sus primeros pasos en la revista Contorno (1953-1959). La figura destacada, que marcará la continuidad entre la publicación inicial y la formación del MLN, será Ismael Viñas. Junto con él, Ramón Alcalde, Susana Fiorito y Noé Jitrik, participaron en un primer momento de la experiencia de Arturo Frondizi, a quien terminaron criticando y combatiendo. La lucha de la laica y libre, marcó el primer punto de ruptura; la apertura a capitales extranjeros en condiciones "no favorables", el "problema petrolero", la represión en el frigorífico Lisandro de la Torre y la promulgación del Plan Conintes, implicaron la separación total de la experiencia. De esta manera, luego de una interna en la Unión Cívica Radical Intransigente (UCRI), en 1960 conformaron el MLN y a partir de 1962 editaron su órgano político, Liberación. A pesar de la fecha que marcó el comienzo, fue recién en 1964 que comenzó un planteamiento integral de la cuestión programática.

\footnotetext{
${ }^{7}$ S. Gorbán había sido promotor del Grupo Rosario, conformado por universitarios no peronistas favorables a las políticas de planificación y desarrollo industrial, y un economista de renombre en la UNL del pos-peronismo. En dicha universidad fue docente, decano y consejero entre los años 1955 y 1966. Los temas que investigó giraron en torno a la planificación del desarrollo industrial en Argentina y América Latina, ideas que acompañó con un marcado activismo a favor de los pequeños y medianos industriales de la provincia de Santa Fe y el Gran Rosario. Al respecto, véase: De Marco (2012) y Simonassi (2016).

${ }^{8}$ En la regional Capital militaban Francisco 'Paco" Urondo', Ricardo Scaricabarozzi, Beatriz Broitman, "Negro" Ezcurra, Celia Guevara (madre de Ernesto "Che" Guevara), Magú, Haydee Gurassa, Madrazo, "Manolo", Marcos Schlachter, Mauricio Luqui, Pedro Pasturenzi, Sergio Bufano y quince militantes más (Pacheco, 2012, pp. 132-133).
}

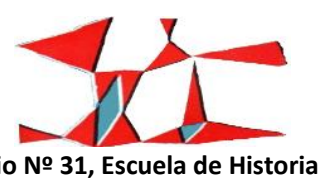


MATIAS J. RUBIO

En sus primeros documentos el agrupamiento consideró a la Argentina como un país dependiente, con un desarrollo capitalista deformado, que no había logrado constituirse como nación. A su vez, remarcó que el desarrollo logrado hasta el momento se había podido concretar producto de la acción de una "burguesía oligárquica" que, asociada al imperialismo británico, habría explotado al país como una colonia agrícola-ganadera. Su programa, de liberación nacional y social, sostuvo la defensa del pequeño y mediano capital frente al capital imperialista y sus socios nacionales. Sin embargo, en su planteo estratégico, consideró a la burguesía nacional incapaz de desarrollar ese programa, según el MLN, el yrigoyenismo y el peronismo habían fracasado en sus intentos. En consecuencia, defendió la dirección del proceso político por el proletariado urbano y sostuvo la necesidad de una alianza con diferentes sectores oprimidos: los obreros rurales, las clases medias y grupos de la burguesía nacional. En cuanto a la existencia o no de campesinado en el país, el MLN negó su existencia como clase, esta impresión formaba parte de la crítica realizada por la organización a los partidos de izquierda que, en su parecer, sacaban esta conclusión a partir de trasladar esquemas europeos a la realidad rioplatense. De esta manera, el campesinado no podía jugar un papel preponderante (como había ocurrido en los casos de las revoluciones rusa y china), ni desde el punto de vista cualitativo ni desde el cuantitativo (Pacheco, 2012). En este punto, las producciones posteriores de Gastiazoro darán un vuelco total.

Gastiazoro, colaboró con aquella construcción programática que, a partir de 1968, entraría en una profunda y terminal crisis. Con Ismael Viñas escribió Economía y Dependencia (Gastiazoro y Viñas, 1968), que fue en la línea del programa de la organización. Pese a la coautoría, Gastiazoro reconoce que "todo lo económico, lo escribí yo. Se lo pasé a Ismael (...). No es que lo escribimos juntos. Él agregó base y la línea del MLN, él ajustaba las consideraciones que tuvieran que ver más con lo político" ${ }^{9}$.

En 1968, estalló el primer conflicto interno, donde se acusó a Susana Fiorito de no estar a la altura, en términos organizativos, de la radicalización que estaba experimentando la situación política argentina: un manejo administrativo que no era funcional al nuevo rol que debía cumplir el agrupamiento en la construcción de una opción revolucionaria. Finalmente, la dirigente terminó siendo desplazada de su cargo de dirección y Gastiazoro operó en su defensa. Esta crisis, que comenzó planteándose problemas organizativos, terminó en un cuestionamiento generalizado del programa construido por la organización.

\footnotetext{
${ }^{9}$ Entrevistas a Eugenio Gastiazoro, op. cit..
}

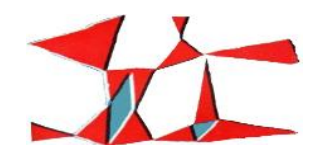




\section{Eugenio Gastiazoro: del MLN al PCR, de la Economía a la Historia (1965-1989)}

En esta última etapa, la discusión giró en torno a la existencia o no de tareas democrático - burguesas pendientes de resolución en el país. Es decir, en torno al carácter de la revolución en Argentina: si debía plantearse la liberación nacional o la realización directa del socialismo. Eugenio Gastiazoro, que había quedado a cargo de la redacción de Liberación, defendió en febrero y abril de 1969 al gobierno nacionalista peruano de Juan Francisco Velazco Alvarado porque había tomado medidas de tipo nacionalistas, como la expropiación del complejo petrolero y el establecimiento de un impuesto a la propiedad rural, y señaló que la tarea de las organizaciones revolucionarias era presionar sobre el gobierno nacionalista e intentar colocar al proletariado en la dirección del proceso ${ }^{10}$. De esa manera, E. Gastiazoro se pronunció, a diferencia de Ismael Viñas, por la existencia de tareas democráticas pendientes y la necesidad de conquistar la liberación nacional, posición que reforzaría en futuros trabajos.

Luego de un intenso debate, a fines de 1969, una reunión en la provincia de Córdoba votó la disolución del MLN, impulsada por Viñas. Frente a esto, los militantes enfrentados a la resolución formaron el Núcleo de Izquierda Revolucionaria (NIR). Entre estos se encontraba E. Gastiazoro que comenzó planteando una discusión estratégica alrededor de lo que, en su entender, debía pensar el nuevo grupo para superar las "limitaciones movimentistas" del disuelto agrupamiento: principalmente la construcción del partido revolucionario de la clase obrera y el establecimiento de un programa que dé cuenta de la situación nacional concreta

Un planteo coherente con la línea de Partido hace necesaria una definición clara y delimitada de los carriles de clase que uno elige (la clase obrera en este caso) y la dirección de los elementos en la táctica, dentro de un planteo estratégico que lleve a esa clase hacia la conquista del poder político ${ }^{11}$ y concluía señalando que suscribía a lo que sostiene el PCR que 'por nuestra realidad nacional, el partido tiene que estar a la cabeza de la lucha antiimperialista, pero desde una posición proletaria, que al diferenciarlo nítidamente, le permita golpear junto con otros sectores, sin llevar agua al molino del capitalismo y acumulando fuerzas en cambio para la alternativa insurreccional y proletaria'12

De esta manera, a pesar de reconocer opciones posibles y viables presentadas por la izquierda argentina, puntualmente por Política Obrera (PO), Vanguardia Comunista (VC) y el PCR, existía una inclinación

\footnotetext{
10 “Perú: golpe a los monopolios”, Liberación, n58, $2^{\circ}$ quincena de febrero de 1969, p. 7; “El nacionalismo peruano”, Liberación, n60, $2^{\circ}$ quincena de abril de 1969, p. 7. Véase al respecto también el trabajo de Pacheco (2012, pp. 277-278).

11 “a todos los compañeros del NIR", Eugenio,7 de diciembre de 1969, Buenos Aires, p. 1.

12 Idem.
}

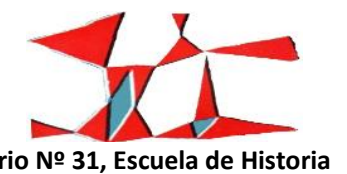


MATIAS J. RUBIO

marcada por la última opción. Sin embargo, recuerda Gastiazoro que "cuando se rompe el MLN, hablé con todos, me buscaron todos... Estaba el PCR que no se preocupó tanto por buscarme, al final tuve que buscarlos yo". Fue una compañera de trabajo del CONADE quien lo contactó directamente con José Ratzer, responsable del periódico del PCR y uno de sus principales cuadros, con quien se reunió "mientras se hacía el primer congreso. El flaco me dice, discúlpame que te cité acá [microcentro porteño], lo que pasa es que tengo que mostrarme". De esta manera, la integración al partido se dio de manera personal y Gastiazoro fue incorporado a la redacción del periódico, Nueva Hora, donde también trabajaba Julio Godio. En paralelo, sin coordinación, se integraron otros militantes del NIR, "gente que había estado conmigo en la ruptura, de Quilmes y de Jujuy", como Carlos Aramayo y Pico Vazeilles. ${ }^{13}$

\section{EI PCR y la construcción del programa revolucionario (1969-1976)}

La incorporación al PCR, entonces, fue de la mano de José Ratzer e implicó su incorporación a un lugar específico de trabajo que implicó una continuidad con sus tareas en el auto disuelto MLN. Mientras continuó trabajando en el CONADE, donde cumplía horarios de oficina, su tiempo fue limitado. El periódico, "Nueva Hora dependía directamente de Secretaría General, depende de Otto [Vargas], y la revista [Teoría y Política] pasó a depender del flaco [José Ratzer], en lo que sería propaganda. Serían dos carriles distintos, pero en la revista escribí desde el principio". Sin embargo, la incorporación a los órganos propagandísticos, no conllevó una incorporación inmediata a la dirección del partido. Será recién en el segundo congreso del PCR (1972) que fue nombrado Secretario de Redacción y, luego, en el tercer congreso (1974), lo nombraron Director del periódico, cuando Julio Godio abandonó la organización. ${ }^{14}$

EI PCR había nacido, oficialmente, en enero de 1968, producto de la expulsión de un grupo dirigente de la Federación Juvenil Comunista (FJC) y de un puñado de cuadros del Partido Comunista (PC). De aquel proceso también participaron miembros del Movimiento Estudiantil Nacional de Acción Popular (MENAP), cuyos cuadros más destacados fueron Rafael Gigli, Carlos “El Vasco” Paillole y Rosa Nassif, entre otros. Luego, antes del primer congreso, se sumarían militantes de la Agrupación de Obreros Metalúrgicos - Felipe Vallese,

\footnotetext{
${ }^{13}$ Entrevistas a Eugenio Gastiazoro, op. cit..

${ }^{14}$ Ídem.
}

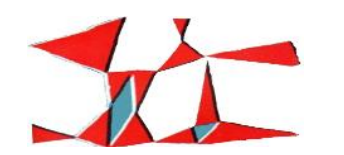




\section{Eugenio Gastiazoro: del MLN al PCR, de la Economía a la Historia (1965-1989)}

entre los cuales se encontraba René Salamanca, y, provenientes del auto disuelto MLN, E. Gastiazoro y Carlos Aramayo, entre otros. ${ }^{15}$

El grupo expulsado del PC se constituyó, en un primer momento, bajo el nombre de Partido Comunista - Comité Nacional de Recuperación Revolucionaria (PC-CNRR). A partir de ese momento, la organización se sumergió en una discusión programática y estratégica que se prolongó hasta su $1^{\circ}$ Congreso en 1969. En un primer momento, el grupo se identificó con el Che Guevara y la revolución cubana. Luego, junto con la adopción de la estrategia insurreccional y el rechazo al foquismo guerrillero, el PCR fue acercándose al maoísmo. Esta filiación teórica, oficializada en 1974, cuando tuvo lugar su 3o Congreso, pero con antecedentes desde 1972, implicó la adopción de la teoría del social imperialismo elaborada por Mao Tsetung (1893-1976) quien consideró la existencia de un escenario en el cual los EEUU y la URSS se disputaban el control imperialista de los países del Tercer Mundo.

Durante ese proceso de empalme con el PCR, E. Gastiazoro elaboró una serie de libros y artículos donde plasmó sus consideraciones e ideas políticas. En ellos, buscó articular sus producciones escritas con su acción política, desempeñando un rol importante en la construcción política partidaria y la difusión de las posiciones partidarias desde el punto de vista propagandístico.

Los primeros libros que aparecieron luego de su incorporación fueron Critica del Desarrollismo (Gastiazoro, 1970) y Desarrollismo o Socialismo. Una Alternativa Argentina (Gastiazoro, 1971), donde se estableció una disputa con el desarrollismo en tanto considerarla una "salida burguesa a la crisis nacional". En términos de la caracterización y crítica de esta corriente de pensamiento ambos libros fueron en el mismo sentido, constituyendo el segundo prácticamente una reedición del primero con un nuevo título, pero con una modificación sustancial respecto a la salida política propuesta para la crisis del país.

En Critica del Desarrollismo, Gastiazoro sentó las bases del ataque a esta corriente de pensamiento, al sostener que estas teorías partían del desconocimiento de la dinámica real de la sociedad capitalista, a partir de la naturalización el régimen social imperante. De esta manera, las teorías para el desarrollo “aparecen como meras 'técnicas', y el carácter clasista de las mismas trata de ocultarse deliberadamente". Asumiendo un materialismo histórico que enfatiza en la contradicción de las relaciones sociales de producción y el desarrollo de las fuerzas productivas, propuso una crítica integral a las teorías del desarrollo que, según

${ }^{15}$ Para una aproximación a los sectores que confluyeron en la formación del partido, véase: Andrade (2007), Grenat (2011); Sánchez, (2008), Pacheco (2012), Brega (1990), Lissandrelo (2009), Rupar (2018; 2017; 2016), Siskindovich (2020), Laufer (2018), Gilbert (2009) y Rubio (2017).

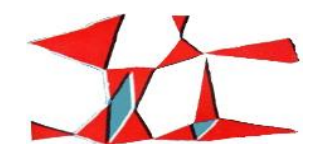

Anuario № 31, Escuela de Historia

Facultad de Humanidades y Artes (Universidad Nacional de Rosario), 2019 ISSN 1853-8835 
MATIAS J. RUBIO

respondieran a determinados sectores de la burguesía, tomarían diferentes formas. Para ello, partió de ubicar históricamente su emergencia "con la época de expansión del capital monopolista", la época imperialista del desarrollo del capitalismo. Sin embargo, estas habrían tenido su origen en la región en la crisis del '30 cuando habría cambiado radicalmente la división internacional del trabajo hasta entonces existente que implicaba que los países centrales producían manufacturas y los periféricos materias primas y alimentos (Gastiazoro, 1970, pp. 15-20).

En ese marco general, Argentina es definida como un país capitalista dependiente, cuyos designios habían sido dominados, hasta el Crac del '29, por la oligarquía terrateniente que habría logrado acoplar el desarrollo del país a las necesidades del capital monopólico. En paralelo, sostiene Gastiazoro, habría crecido una "burguesía industrial mediana" a la que la situación internacional, sobre todo la Segunda Guerra Mundial, terminó enfrentando a la oligarquía local y el capital monopolista abriendo un curso de industrialización enfrentada al mercado mundial. Producto de dichas condiciones históricas surgiría el peronismo: una experiencia que, aunque habría planificado la economía con base en la burguesía nacional, no había logrado transformar las condiciones estructurales que hacían al país dependiente del capital monopólico internacional. Luego de esta experiencia trunca, habría surgido el desarrollismo "como expresión de una burguesía que ha abandonado la perspectiva nacionalista del peronismo para integrarse al imperialismo y confiar al desarrollo impulsado por el mismo la solución de sus problemas internos". En definitiva, la experiencia encarnada y las ideas defendidas por Arturo Frondizi y Rogelio Frigerio representarían "la cobertura ideológica que utilizan algunos burgueses para dar base política a su intento real: el de lograr asociarse al imperialismo, como modo de subsistir" (Gastiazoro, 1970, pp. 47-48).

El punto de llegada, de aquellos enunciados principales, fue un señalamiento de las limitaciones de la burguesía nacional en tanto sujeto histórico, un argumento contenido en las postulaciones programáticas desarrollada por el MLN. La tarea pendiente, según Gastiazoro, era "la lucha por la liberación nacional, que expresa las necesidades de expansión de las fuerzas productivas internas y las tendencias a construir una nación autónoma" que se conjugaría con "la lucha por la liberación social, pues el rompimiento de las trabas que se oponen al desarrollo de las fuerzas productivas solo es posible rompiendo las bases mismas de las relaciones de propiedad, y las de producción, del sistema capitalista-imperialista" (Gastiazoro, 1970, p. 145).

En Desarrollismo o Socialismo, el autor cambia, en el sentido de una precisión mayor, la formulación respecto a la liberación nacional y al reconocimiento de las trabas al progreso nacional. Mientras en el primero

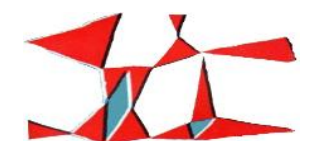

Anuario № 31, Escuela de Historia

Facultad de Humanidades y Artes (Universidad Nacional de Rosario), 2019

ISSN 1853-8835 


\section{Eugenio Gastiazoro: del MLN al PCR, de la Economía a la Historia (1965-1989)}

define la contradicción principal en el país, sin nombrar a los terratenientes, como la existente entre "la clase obrera y los sectores opresores: la burguesía oligárquica y el imperialismo" (Gastiazoro, 1970, pp. 150-151); en el segundo se los incorpora a las clases dominantes, que serian "la burguesía monopolista y terrateniente y los monopolios internacionales", y se incluye, en el polo revolucionario al campesinado, como aliado de "la clase obrera (...) y demás sectores populares" (Gastiazoro, 1971, p. 159). De la misma manera, mientras en el primero se alude a la formación de un movimiento revolucionario con hegemonía de la clase obrera, en el segundo se sostiene que "la clase obrera, organizada en su propio partido, se convierte en el motor del frente de liberación colocándose a la cabeza de la revolución popular, agraria y antimonopolista" (Gastiazoro, 1971, p. 161).

Este desplazamiento expresó, por un lado, la adopción de la elección partidaria y su correspondientes planteos estratégicos y programáticos, y, por otro, la incorporación de la clase terrateniente, a su producción política e intelectual, ya no simplemente como parte de la "burguesía oligárquica", sino como una clase social específica a derrotar. En ese sentido, en términos programáticos Gastiazoro confluía con el naciente PCR al proponer la expropiación sin pago del latifundio, el reparto de la tierra al campesinado pobre y medio y el establecimiento de medidas tendientes a la colectivización (Gastiazoro, 1971, p. 162; PCR, 2005a, p. 408).

En paralelo, Eugenio Gastiazoro fue publicando, en los órganos de propaganda del partido, una serie de trabajos en torno a la cuestión agraria. En ellos, como parte de la discusión programática que se daba en la organización, abordó la problemática de la propiedad de la tierra desde la perspectiva de la productividad y las clases sociales que se enfrentaban en dicho proceso. La conclusión que presentó Gastiazoro fue que la principal traba a la expansión de las fuerzas productivas en el campo se originaba en la propiedad privada latifundista que habría implicado la apropiación, por parte del terrateniente, de la renta absoluta. En cuanto al peronismo, señaló sus limitaciones y vínculos con los terratenientes, al igual que el yrigoyenismo. En términos estratégicos, volvió a señalar que la propiedad de la tierra era el principal problema y planteó que la revolución derivada del desarrollo histórico nacional tendría características democráticas, por su contenido (nacionalización de la tierra), y estaría dirigida a eliminar la base del poder oligárquico: la propiedad privada latifundista. ${ }^{16}$

El empalme programático más significativo de Gastiazoro con el PCR se dio a partir de aquel momento. Con la publicación de Argentina Hoy. Capitalismo dependiente y estructura de clases (1972) el

\footnotetext{
${ }^{16}$ Para un análisis de este debate véase: Rubio (2018a).
}

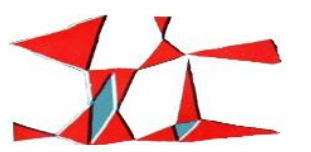

Anuario № 31, Escuela de Historia 
MATIAS J. RUBIO

autor comenzó un trabajo de largo aliento donde intentó construir un conocimiento científico integral respecto a las características del capitalismo argentino y sus clases sociales. Como veremos, el trabajo inicial fue reeditado en dos oportunidades, en 1973 bajo el mismo título y en 1975 como Argentina Hoy. Latifundio, dependencia y estructura de clases (es decir, con una ligera modificación en su título), y cada una de ellas implicó una reformulación atravesada por los avatares políticos y la acción del partido que integraba. De esto último nos encargaremos a continuación.

El libro de 1972, consta de cuatro capítulos que atraviesan los puntos neurálgicos, a su entender, de la naturaleza del capitalismo argentino: la cuestión agraria, concentración monopolista e imperialismo, explotación y pauperización de la clase obrera y, finalmente, las clases sociales y sus programas. Desde un punto de vista general, podemos decir que este libro, al igual que sus sucesores, implicó la reformulación y profundización de aspectos esbozados previamente. Puntualmente se extendió la argumentación en torno a las "trabas objetivas" al desarrollo del capital y la incapacidad de la burguesía para superar dicha situación de crisis, intentando articular un diagnostico general de la situación histórica, con fuerte carga empírica, con una salida política que contemplara la complejidad expuesta. De esta manera, el primer libro estableció la estructura que respetaran los siguientes. En él Gastiazoro concluyó señalando que "los aspectos dominantes de la propiedad sobre la tierra y demás medios de producción, determinantes de las actuales relaciones de producción, son la propiedad terrateniente y el capital monopolista e imperialista" y, por lo tanto, "la contradicción burguesía versus proletariado no aparece nítida sino que está inscripta en o subordinada a la contradicción oligarquía burguesa terrateniente e imperialismo versus clase obrera, campesinado pobre y medio, asalariado y pequeña burguesía urbana". En la formula, de aquel polo revolucionario, estaba excluida la burguesía nacional. Dicho sector social, no podía jugar ningún papel en aquel proceso por, además de que su "incapacidad revolucionaria" era "un fenómeno histórico universal", "su relativo debilitamiento y progresiva subordinación frente al avance de la burguesía monopolista y terrateniente y del capital monopolista internacional". De esta manera, solo el proletariado aparecía "personalizando un proyecto social alternativo" (Gastiazoro, 1972, p. 130-131).

La segunda edición, de 1973, volvió a insistir en la imposibilidad de una vía de desarrollo "burguesa independiente". Estando ya en el poder Héctor J. Cámpora, Gastiazoro sostuvo, coincidiendo con el PCR, que no se había producido un "traspaso del poder de las manos de la oligarquía burguesa-terrateniente a las manos de la clase obrera y el pueblo", que tampoco había "ningún indicio de que el nuevo gobierno vaya a

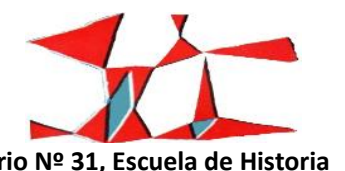




\section{Eugenio Gastiazoro: del MLN al PCR, de la Economía a la Historia (1965-1989)}

realizar el programa de transformaciones necesarias que aspiran las masas obreras y populares" y que, en definitiva, lo que terminaría ocurriendo era que el gobierno peronista desarrollaría "una política de reacomodamiento en las relaciones de las clases dominantes con el imperialismo, tratando de apoyarse en la creciente rivalidad interimperialista" sin atacar "las bases del atraso y la dependencia" (Gastiazoro, 1973, pp. 202-205).

El gran cambio se produjo con la edición del año 1975. El propio autor, ante las modificaciones introducidas, puntualiza en el prólogo que debe ser "considerarlo como otro libro". Pese a algunas modificaciones parciales y un notable incremento de base empírica, la estructura analítica prácticamente es la misma, siendo la modificación más sustancial la referida a la caracterización del rol desempeñado por la burguesía nacional. Partiendo de considerar que 1969 había producido "un poderoso resurgir de la lucha antidictatorial y antiimperialista", se planteó que aquel movimiento había empujado a la resistencia a "sectores cada vez más amplios de la burguesía nacional, en un trasfondo de creciente injerencia de las potencias rivales de los Estados Unidos, particularmente de la otra superpotencia, la Unión Soviética”. Aquel nuevo imperialismo en la escena no cambiaba "la incapacidad histórica de la burguesía nacional", expuesta en los anteriores libros, sino que ahora, en las nuevas condiciones, planteaba que "el proletariado puede y debe trazarse una política de alianzas que le permita ganar a los sectores patrióticos y democráticos de la burguesía nacional y neutralizar a los otros, en la lucha patriótica liberadora”. De esta manera, en la fórmula que indicaba la contradicción fundamental del país se introdujo una pequeña, pero significativa, modificación que colocó a "los sectores patrióticos y democráticos de la burguesía urbana y rural” en el mismo polo social que a "la clase obrera, los campesinos pobres y medios, la pequeña burguesía urbana, la mayoría de los intelectuales y estudiantes" que se contraponían "al imperialismo, la oligarquía terrateniente y el gran capital a ellos asociado" (Gastiazoro, 1975, pp. 5 y 210-224).

Este movimiento empalmó con tres desplazamientos que se habían producido, al menos, un año antes en el partido. Por un lado, con lo que, en 1974, el PCR había resuelto en su Tercer Congreso respecto al

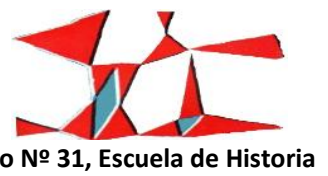


MATIAS J. RUBIO

carácter de la revolución ${ }^{17}$; por otro, con la adopción de la teoría del "socialimperialismo ruso"18 y; por último, con la crítica realizada por Horacio Ciafardini a la "teoría del capitalismo dependiente". Esta última, apareció en la revista teórica del partido en noviembre de 1975, pero Gastiazoro tuvo acceso a ella con antelación: era un tema que se venía discutiendo en el partido y había tenido un impacto significativo en las discusiones congresales de 1974. Allí Ciafardini, focalizando sus críticas a la "teoría de la dependencia", consideró que "el fracaso de la burguesía nacional en pugna con el imperialismo muestra que esa clase no es capaz de dirigir al conjunto del pueblo hasta la victoria contra su enemigo principal, pero no que la burguesía nacional y los gobiernos que de ella provienen, hayan de caer necesariamente en manos de los enemigos". En ese sentido, Ciafardini balanceó todo el recorrido teórico previo que habría llevado al PCR a cometer errores, posiciones "ultraizqueirdistas" y "trotskizantes", y las nuevas consideraciones que guiaban la acción política del partido. En el pasado, haber definido un "polo reaccionario de las contradicciones (...) como 'el gran capital, la oligarquía terrateniente y los monopolios extranjeros"” no habría permitido "dar cuenta de los acontecimientos en que se ponían de manifiesto las divisiones políticas profundas de esas clases y sectores", pero, de allí en más, debían tomarse "en cuenta seriamente las posibilidades que esos grupos tenían de jugar en la política contra el enemigo principal" que para el momento eran los norteamericanos. De esta manera, en términos estratégicos, en articulación con la política que desarrollaba el partido, el economista propuso un "Frente Único Antiyanqui con hegemonía proletaria", pero reconoció que esa "propuesta se ve obstaculizada por la posición golpista del socialimperialismo y los sectores a él ligados" (Páez, 1975, pp. 1325).

En retrospectiva, Gastiazoro señala que, tal crítica teórica, les permitió comprender que "los teóricos del capitalismo dependiente no diferenciaban en la burguesía nacional a los sectores limitados en su desarrollo por el imperialismo y el latifundio, y la golpeaban en bloque, junto con el imperialismo y la

\footnotetext{
17 En 1974, en términos programáticos, el PCR caracterizó que la contradicción fundamental era la que oponía al imperialismo, la oligarquía terrateniente y el gran capital a ellos asociados, por un lado, y, por el otro, a la clase obrera los campesinos pobres y medios, la pequeña burguesía, la mayoría de los estudiantes e intelectuales y sectores patrióticos y democráticos de la burguesía urbana y rural (PCR, 2005b, p. 93)

En este sentido, partiendo de considerar a la Argentina como un país con predominio de relaciones de producción capitalistas, pero deformadas por la dominación imperialista y el latifundio de origen precapitalista, consideró necesaria una "revolución democrático-popular, agraria, antiimperialista y antimonopolista, en marcha al socialismo". Respecto a este último punto, el PCR puntualizó que, en aquella primera etapa democrática de la revolución, "la contradicción proletariado-burguesía es una contradicción secundaria. Pasará a ser la contradicción fundamental a resolverse en la etapa socialista de nuestra revolución" (PCR, 2005b, pp. 93-94).

${ }^{18}$ Para una periodización y explicación del proceso de la adopción e instrumentalización de este concepto por parte del PCR, véase: Rubio (2018b).
}

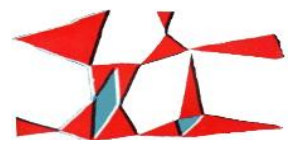

Anuario № 31, Escuela de Historia 


\section{Eugenio Gastiazoro: del MLN al PCR, de la Economía a la Historia (1965-1989)}

oligarquía"19. En gran medida, aquel desplazamiento teórico tuvo su impacto en la política que el PCR comenzó a desarrollar, apoyando, luego de la muerte de Perón ${ }^{20}$, al gobierno de Isabel Martínez de Perón ${ }^{21}$.

\section{De la Economía a la Historia (1976-1989)}

Cuando se produjo el golpe de marzo de 1976 a Gastiazoro lo echaron del CONADE y pasó a la clandestinidad. Estando su mujer e hijos en Brasil, se instaló en un departamento que presentaba condiciones de seguridad y desde allí, en constante contacto con Otto Vargas, editó el periódico partidario, que siguió saliendo con menor frecuencia, por quincena, y del que había quedado como único responsable.

En ese complicado contexto, donde fueron asesinados y secuestrados algunos militantes del PCR, salió a la calle El problema agrario argentino y sus soluciones (1976). Desde ya, un libro editado en mayo de 1976 y que concluía sentenciando que "el problema agrario argentino se encuentra estrechamente vinculado con el problema de la dependencia y su solución depende, como la de esta, de transformaciones revolucionarias en el conjunto de la sociedad", tuvo una circulación muy limitada. Publicado por la editorial Paidos, allí se abordó "el modo en que se desarrolla la producción agropecuaria", donde se encontrarían los elementos que determinarían la orientación de la economía nacional, y concluyó señalando que, frente a la traba impuesta al desarrollo de las fuerzas productivas, había dos "grandes rubros" de propuestas para solucionar el problema agrario. Por un lado, "la terrateniente" que consistía en "estimular el desarrollo del capitalismo sobre la base de las grandes extensiones territoriales". Por otro, "la manera campesina de resolver el problema, que significa una forma verdaderamente revolucionaria", por la que se toma partido (Gastiazoro, 1976, pp. 10-15 y 80-89).

Por otro lado, en 1978 apareció, editado por el Centro Editor de América Latina, Léxico de economía. Como su nombre lo indica, este libro es un compendio de conceptos donde predomina una visión marxista (Gastiazoro, 1978). Desde un punto de vista integral, podemos decir que estos dos últimos materiales implicaron un corte. A partir de allí Eugenio Gastiazoro experimentará un total vuelco a la escritura de la Historia.

\footnotetext{
${ }^{19}$ Entrevistas a Eugenio Gastiazoro, op. cit..

20 “Teniente Juan Domingo Perón”, Nueva Hora; n 145, 2 quincena de julio de 1974, p. 12.

21 "Apuntan a Isabel”, Nueva Hora; n 187, del 2 al 9 de julio de 1975, p. 1.
}

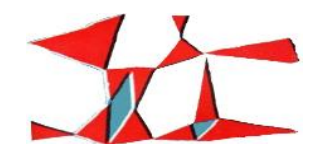


El economista recuerda que como "ya no trabajaba en el CONADE, tenía que hacer algo. Entonces me puse a leer y a escribir sobre historia, tenía tiempo de sobra". Por otro lado, en torno a los motivos de aquel vuelco, simplemente recuerda que "de la historia alguna idea tenía antes, pero... la primera vez que se me ocurre escribir algo de historia, fue a partir de que estuve en Rosario, estudiando el doctorado. Fue a Filosofía y Letras Nahuel Moreno. Al escucharlo dije ahí hay que revisar la historia, hacer un enfoque marxista de esta historia argentina. Entonces empecé a pensar en eso. Por ahí levantaba cosas como lo del IAPI que era mi tema de tesis... sin diferenciar". Sin embargo, hay dos tipos distintos de antecedentes centrales que actuaron como un puente y le sirvieron de base para estructurar su indagación histórica. Por un lado, los trabajos de Otto Vargas en torno al modo de producción dominante en el Rio de la Plata durante el periodo colonial, que habían aparecido entre 1976 y 1977 . Allí, el dirigente del PCR, destacó la inexistencia de un modelo puro de capitalismo o feudalismo, pero remarcó que eso no negaba la existencia de leyes universales que regían el desarrollo de las sociedades: el feudalismo en América, había tomado su propia forma, por ejemplo, con la encomienda que no había llegado a ser ni un feudo, ni un señorío típico, pero no por ello menos feudal (Irusta, 1976, 1977; Vargas, 1985).

En otro plano, su experiencia previa que estuvo compuesta de dos tipos de registros. Por un lado, sus trabajos anteriores utilizaban la historia para explicar determinados fenómenos económicos que tenían continuidad en distintos periodos. Por otro, en 1971 dictó, a pedido de un grupo de estudiantes "que me vino a buscar", clases en "la catedra de Historia Económica y Social en Económicas de la UBA"22. Tal aventura le valió un procesamiento por "usurpación de catedra" que implicó, a pesar de ser absuelto, pasar un fin de semana en la cárcel de Devoto.

Con esos antecedentes, entre 1976 y 1978, escribió lo que en 1980 se publicó en un tomo (Gastiazoro, 1980) y en 1986 en dos (Gastiazoro, 1986a, 1986b), ambos por la recién fundada editorial partidaria Ágora. Pese a las condiciones de clandestinidad, recuerda que "tenía la ayuda del flaco [José Ratzer]. En la

\footnotetext{
22 "me fueron a buscar los estudiantes de Historia Económica y Social, que expulsaron de la cátedra al profesor Lagos, creo que así se Ilamaba, y me llevaron a que diera la cátedra. Di una clase en el aula correspondiente, que después fue clausurada con candados, así que las posteriores fueron en las escaleras. Frichtneck hizo grabar y fotografiar todo y elevó una denuncia contra mí por usurpación de cátedra a la llamada Cámara del Terror, el fuero especial oral creado por la dictadura de Onganía. Fui detenido con preventiva, salí por la movilización solidaria de los estudiantes, aunque siguió el proceso en juicio oral, con la defensa del Doctor Edmundo Hendler, en ese momento un socialista defensor de la libertad de cátedra. El juicio se ganó y en la Facultad, por la lucha estudiantil, se produjo el cambio de Frichtneck por Campbell. Con la asunción de Cámpora en 1973, volvimos a la facultad con el nuevo decano Oscar Sbarra y estuve como titular de Historia Económica y Social hasta la intervención de la Universidad por Ottalagano en 1974, donde ya no nos dejaron volver a entrar". Entrevistas a Eugenio Gastiazoro, op. cit..
}

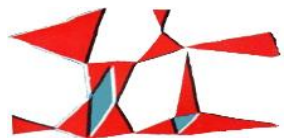

Anuario № 31, Escuela de Historia 


\section{Eugenio Gastiazoro: del MLN al PCR, de la Economía a la Historia (1965-1989)}

clandestinidad nos encontrábamos en el Caballito Blanco, ya teníamos fijado día y hora. Entonces ellos [Otto Vargas y J. Ratzer] me pasaban las cosas y comentábamos". Una vez terminado, se sacó

una edición interna, clandestina. Que se hizo en mimeógrafo. No sé cómo le llegó, pero la agarró Favaloro [Rene] y en una cosa que él escribió sobre San Martin, me cita a mín ${ }^{23}$. Al enterarnos de que él había sacado eso, el compañero que estaba a cargo de la editorial lo va a ver con motivo de que queríamos reeditarlo... y el tipo dice 'bueno yo voy a financiar, yo estoy de acuerdo'... él tenía esa idea de que la educación te resuelve todo. Entonces decía que era un libro que tiene que estar en todos lados, en la escuela. Y bueno, en esa época nos dio 10 mil y era uno a uno, o antes del uno a uno... no me acuerdo. Bueno, mucha plata. Tanta que los dos primeros tomos, se hicieron a base de lo que él puso. Eso fue lo que permitió después que siguiera yo con el tercero y llegara al cuarto ${ }^{24}$. Ya el cuarto, ese sí que se dio un poco por encargo... en el sentido de que ya el partido pedía el cuarto ${ }^{25}$.

La hipótesis que conecta estos nuevos materiales con los producidos anteriormente, es la idea de que la revolución, y nada más que ella, podía desencadenar el desarrollo de las fuerzas productivas del país, superando las trabas objetivas cuyo principal problema era la existencia del latifundio. En ese sentido, los análisis históricos de Gastiazoro se ocuparon de identificar "sobre qué bases se ha ido conformando la sociedad argentina" y de qué manera, a raíz de los múltiples cambios ocurridos y los distintos episodios de la lucha de clases, se habían ido manifestando las contradicciones y las crisis que ponían "en cuestión a una formación social y su base económica, mostrándola incapaz de dar cauce al desarrollo de todas nuestras potencialidades". De esta manera, en su abordaje hizo énfasis en determinados puntos neurálgicos que coincidían con el sentido común de la historiografía nacional, pero que planteaba la progresividad o no de determinadas ideas frente a otras, tomando partido.

Desde una perspectiva general, la obra elaborada por Gastiazoro, erigida contra "la historia acartonada que (...) enseñan en los colegios y universidades", no discute frontalmente con otras corrientes historiográficas de forma sistemática. Más bien, se organizó con el objetivo de plasmar la posición oficial del partido sobre la historia nacional, dando lugar a una escritura que solo por momentos entra en polémica, y,

\footnotetext{
${ }^{23}$ René Favaloro citó, en su libro ¿Conoce usted a San Martin? (2017), la obra de Gastiazoro, junto con la Historia de la Argentina 1515-1943 (1954) de Ernesto Palacio y De la revolución de independencia a la confederación rosista (1972) de Tulio Halperin Donghi, considerándolo parte de las "obras fundamentales que, durante años, me fueron nutriendo en el conocimiento profundo del alma sanmartiniana" y portadoras de un pensamiento que evitaba caer en "sectarismos" (Favaloro, 2017, p. 263).

24 Se refiere a la publicación de dos tomos más que completarían su visión integral de la Historia Argentina (Gastiazoro, 1986c, 2004)

${ }^{25}$ Entrevistas a Eugenio Gastiazoro, op. cit..
}

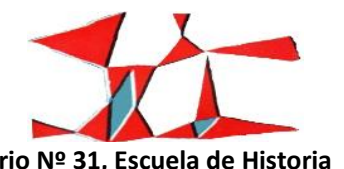

Anuario № 31, Escuela de Historia 
MATIAS J. RUBIO

por tal razón, pudo ocupar el lugar de manual de estudio y formación para la militancia partidaria ${ }^{26}$. A pesar de ello, advertimos que, a lo largo de su desarrollo, el autor se distancia de una serie de interpretaciones sostenidas por distintas tradiciones historiográficas: por ejemplo, de la encarnada por el PC en lo concerniente al gobierno de Bernandino Rivadavia, al considerarlo como una encarnación de "las ideas de la burguesía europea en la época", pero no de "las ideas de la burguesía revolucionaria" y de un sector de la revisionista al sostener que "somos antirrosistas porque somos antifeudales"27 (Gastiazoro, 1986b, p. 139). En cuanto a su estructura, la obra está articulada alrededor de un hilo conductor problemático, la hipotética existencia de una matriz que habría subsistido a los diversos movimientos políticos y revolucionarios desarrollados en el país, que es analizado respetando la periodización clásica de la historiografía precedente y emitiendo juicios de valor respecto a la progresividad de determinados personajes y procesos. En su reconstrucción, el autor cita diversidad de autores, académicos o no, que le proporcionan información, argumentos y fuentes editas para validar sus ideas - mostrando una actualización bibliográfica importante ${ }^{28}$-, pero, aunque se valga de ellos para delimitarse y construir contrapuntos, de ninguna manera esto implica que su obra este articulada alrededor de las polémicas interpretativas. Estas últimas, son hiatos en una explicación lineal y ordenada en bloques temporales correspondientes al sentido común de los abordajes históricos precedentes. De esta manera, evitando la discusión frontal y limitándose al uso predominantemente acrítico de la bibliografía disponible, Gastiazoro desarrolla una escritura que prioriza la forma ensayística, en detrimento de una escritura académica y la compulsión sistemática de fuentes.

A pesar de que dedica un primer tercio del primer tomo al análisis del período colonial, la revolución de mayo y su desenlace posterior son los elementos más discutidos de la obra. Para el periodo colonial, propuso un análisis fundamentado en los trabajos previos de Otto Vargas ${ }^{29}$, defensor de la tesis feudal de colonización americana, quien intentó explicar el proceso de gestación de un cumulo de contradicciones que habrían hecho estallar la revolución de comienzos del siglo XIX. En esa perspectiva, la revolución, para Gastiazoro, se dio "en la época de la revolución burguesa a nivel mundial" y, por lo tanto, "los distintos

\footnotetext{
${ }^{26}$ Su impacto al interior del partido se manifiesta en la amplia difusión realizada en las publicaciones partidarias y el uso de sus ideas en diversas producciones posteriores de militantes del partido. Respecto a esto último, por ejemplo, Hugo Caffera -médico de la localidad bonaerense de Hurlingham y dirigente del partido desde mediados de los años '70- produjo una historia de la educación en el país apoyándose en el libro de Gastiazoro (Caffera, 2000).

${ }^{27}$ Véase el contrapunto, por ejemplo, en el abordaje de la historiografía comunista realizado por Omar Acha (2009, pp. 133-195).

${ }^{28}$ Además de la literatura partidaria, se citan autores del canon liberal como Bartolomé Mitre, Vicente Fidel López, Emilio Ravignani y Ricardo Levene, y académicos contemporáneos tales como José Carlos Chiaramonte, James Scobie, Carlos Sempat Assadourian, Sergio Bagú, Roberto Cortes Conde, Ezequiel Gallo, Haydee Gorostegui de Torres y Tulio Halperin Donghi, entre otros.

${ }^{29} \mathrm{Al}$ respecto véase Rubio (2018c, pp. 153-158).
}

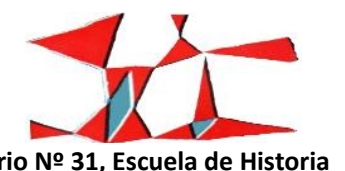

Anuario № 31, Escuela de Historia

Facultad de Humanidades y Artes (Universidad Nacional de Rosario), 2019 ISSN 1853-8835 


\section{Eugenio Gastiazoro: del MLN al PCR, de la Economía a la Historia (1965-1989)}

intereses de clase que confluyeron en la gesta emancipadora y los diferentes objetivos que se podían plantear" debían ser analizados en ese marco. Allí habrían confluido, "en el anhelo común de emancipación del yugo español", diferentes sectores como "la aristocracia terrateniente y los grandes comerciantes, (...) hasta los de las clases más oprimidas del sistema" y habrían actuado "las potencias rivales de España" (Gastiazoro, 1986a, pp. 7-141). Frente a esto, “los patriotas” habrían estructurado,

tras el elemento común de la lucha por la independencia (...) un complejo frente político, donde se incluían desde republicanos hasta monárquicos y desde partidarios de la independencia total hasta proingleses y profranceses. Es decir que en la lucha por la independencia se conformó un verdadero frente nacional, que excluía solamente a los partidarios de del monopolio comercial y de la autoridad españoles (Gastiazoro, 1986a, p. 157)

En ese marco, concluyó señalando que "con todas las limitaciones del caso, la más completa proposición de la vanguardia revolucionaria de mayo quedó plasmada a iniciativa de Belgrano y bajo la pluma de Moreno en el Plan de Operaciones". Sin embargo, aquellos no habrían sido más que "los sectores más avanzados de la aristocracia terrateniente criolla, en condiciones en que no se puede hablar con propiedad de la existencia de una burguesía industrial" y la "tragedia" se habría desencadenado con "la destitución de Mariano Moreno, nuestro Robespierre" (Gastiazoro, 1986a, pp. 158-162). Luego, desplazado el sector jacobino de la revolución, "la oligarquía brillante y gloriosa'” no habría podido

escapar a sus determinaciones de clase por lo que careció de una visión nación que le permitiera, aún en las difíciles condiciones de entonces, ir más allá de las pretensiones exclusivistas del puerto de Buenos Aires, y el exclusivismo ganadero de los grandes terratenientes (Gastiazoro, 1986a, p. 191)

Sobre aquellos "intereses latifundistas" se concretaría "la unidad nacional", apoyada en el "sometimiento del inmigrante a condiciones semifeudales". De esta manera, se habría cerrado un proceso abierto por la gesta independentista, que por "la hegemonía de la aristocracia terrateniente y comercial" terminó estrangulando "todas sus posibilidades democráticas". En ese punto, los cambios históricos posteriores son leídos como la adaptación de dicho sector social en pos de retener los elementos estructurales que supo imprimirle al país. Todo esto habría sido facilitado, en la perspectiva de Gastiazoro, por los distintos imperialismos que "no aspiraban a transformar en países adelantados a los países atrasados", sino "a explotarnos aprovechando su atraso, contribuyendo a mantener sus modos de producción antiguos, aliándose con la clase terrateniente dominante y buscando conformar una clase intermediaria en función de

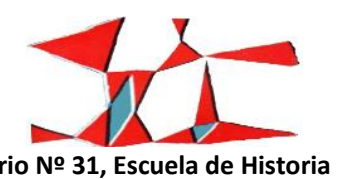

Facultad de Humanidades y Artes (Universidad Nacional de Rosario), 2019 ISSN 1853-8835 
MATIAS J. RUBIO

asegurar su predominio en nuestro mercado" (Gastiazoro, 1986b, pp. 111-143). De este modo, la unificación nacional encabezada por la "oligarquía" habría acallado y derrotado "todas las expresiones de resistencia, incluidas las entonces incipientes de una burguesía nacional" (Gastiazoro, 1986c, p. 9).

Con esas ideas de base -y en subordinación a la hipótesis que consideraba a los terratenientes como una clase social parasitaria, a través de la cual penetraban los imperialismos-, se produjo un desplazamiento temático que implicó comenzar a analizar la actuación de esta clase social a través de la historia. De esta manera, del análisis histórico se concluía que "toda la experiencia (...) demuestra que no podemos liberarnos de los imperialismos sin destruir el poder político y económico de los terratenientes. Las tareas de liberación nacional son inseparables de esa tarea democrática", la reforma agraria (Gastiazoro y Aramayo, 1983, pp. 3845). En estos libros y los trabajos paralelos y siguientes, entonces, puede observarse este movimiento: el intelectual, a partir de la dictadura, comenzó a trabajar temas de Historia Argentina donde, utilizando como puntos de partida los análisis económicos estructurales y de coyuntura que la organización y él mismo habían realizado, los terratenientes ocupaban el lugar central en una trama argumentativa dominada por el problema de la dependencia (Garmendia, 1979, 1980, 1981; Gastiazoro, 1986d, 1987, 1989).

\section{A modo de cierre}

Como hemos expuesto a lo largo de este trabajo, reconocimos diferentes momentos en la trayectoria política e intelectual de Eugenio Gastiazoro. Dicha delimitación nos permitió realizar un abordaje que, centrado en el análisis de sus producciones escritas, buscó dar cuenta de una serie de procesos y problemas representativos, en nuestra consideración, de un contexto y una personalidad: la composición de su entorno familiar, social y cultural, su formación profesional, las condiciones de su acercamiento a la política, los distintos momentos de su participación en el MLN, su incorporación y recorrido en el PCR y, finalmente, su desplazamiento de la Economía a la Historia. En la reconstrucción realizada, advertimos que E. Gastiazoro construyó en sus producciones, más allá de los desplazamientos políticos, una base perdurable (es decir, una serie de tesis y planteos) que conecta el conjunto de su obra alrededor de un problema. Éste -que apareció en el periodo de disgregación del MLN, dejó una marca perdurable en sus elaboraciones posteriores y, a pesar de no haber sido abandonada, experimentó una serie de transformaciones-, fue el que planteó la necesidad de resolución de las tareas democrático-burguesas pendientes en Argentina, donde el problema agrario y la

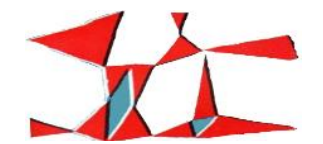

Anuario № 31, Escuela de Historia

Facultad de Humanidades y Artes (Universidad Nacional de Rosario), 2019 ISSN 1853-8835 


\section{Eugenio Gastiazoro: del MLN al PCR, de la Economía a la Historia (1965-1989)}

existencia del latifundio ocuparon un lugar central. En Este punto, señalamos que, por un lado, el condicionamiento de la trayectoria de vida fue central para las ideas desplegadas al respecto y, por otro, que su producción fue moviéndose en consonancia con el rumbo que fue tomando el PCR al respecto. Esta última cuestión debería ser profundizada prestando particular atención a las formas de desacoples y reacomodamientos producidos.

Observando de conjunto su trayectoria política e intelectual advertimos una preminencia de los espacios políticos y partidarios en el despliegue de sus producciones y conocimientos, pese a su presencia en el ámbito académico y profesional. En estos últimos, la argumentación estratégica fue el punto de llegada de sus planteos e ideas, por tal razón nos permitimos plantear que, más que una preminencia absoluta del ámbito político, tuvo lugar una superposición que borró los límites entre uno y otro.

Juzgamos que el rol de este intelectual fue importante en términos políticos, fundamentalmente, porque se ocupó de discutir y proponer qué carácter debía asumir el proceso revolucionario en el país: cuestión cardinal, primero, en una organización que estaba en proceso de disolución y, segundo, en un partido recientemente creado que se encontraba en formación. En este sentido, sostenemos que este personaje se desempeñó, en ambas coyunturas, como un productor de conocimiento para la práctica política, posición que fue habilitada, por un lado, por la situación que atravesaban estas organizaciones respecto a la discusión en torno a su naturaleza y objetivos y, por el otro, por los lugares que ocupó en ellas. Consideramos que su desempeño en el PCR debe ser desdoblado, teniendo en cuenta la existencia de: un primer momento donde el partido se encontraba en proceso de formación y a su interior tenían lugar encendidas discusiones respecto a cuestiones teóricas y programáticas; y, un segundo momento, donde ya se había definido en gran medida el programa partidario y sus publicaciones debieron dar cuenta de posiciones que coincidieran con él, sin dar lugar a las disidencias públicas. Más allá del maoísmo, en el proceso de formación, el PCR se constituyó como un espacio donde diferentes personalidades produjeron una teoría aplicable, como guía de la acción, en la actividad cotidiana del partido. De esta manera, consideramos necesario desplegar estudios similares sobre otras personalidades partidarias -como, por ejemplo: Horacio Ciafardini, Otto Vargas, José Ratzer y Julio Godio, entre otros-, a fin de lograr establecer la especificidad de cada una de las ideas y planteos desplegados en relación a los distintos momentos de la organización.

Habiendo hecho énfasis en la dimensión política de las producciones escritas de Eugenio Gastiazoro en el largo plazo, quedan planteadas una serie de vías para profundizar y complejizar nuestro análisis. Por un

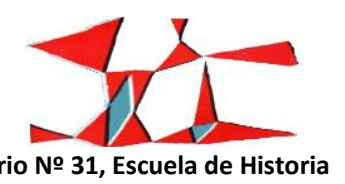

Facultad de Humanidades y Artes (Universidad Nacional de Rosario), 2019 ISSN 1853-8835 
MATIAS J. RUBIO

lado, poner en dialogo su producción con el mundo político y militante contemporáneo a fin de aproximarnos a la especificidad de sus ideas dentro de un marco general y, por otro, recortar el periodo de análisis, incluyendo sus escritos de coyuntura aparecidos en las prensas partidarias, lo que permitirá dar cuenta de los puntos de ruptura y desplazamientos con mayor precisión.

\section{Bibliografía}

Acha, Omar (2009), Historia critica de la historiografía argentina, Vol.1: Las izquierdas en el siglo XX, Prometeo, Buenos Aires.

Andrade, Mariano (2007). Para una historia del maoísmo argentino. Entrevista con Otto Vargas. Buenos Aires: Imago Mundi.

Álvarez, Ignacio (1979). “Notas sobre el problema agrario argentino”. Teoría y Política (22).

Brega, Jorge (1990). ¿Ha muerto el comunismo? El maoísmo en argentina. Conversaciones con Otto Vargas. Buenos Aires: Ágora.

Caffera, Hugo (2000). Educación y luchas populares. Historia crítica de la educación en la Argentina. Buenos Aires: Cinco.

Campione, Daniel (2002), Argentina: la escritura de su historia, Buenos Aires: Centro Cultural de la Cooperación.

De Diego, José Luis (2003). ¿Quién de nosotros escribirá el Facundo? Intelectuales y escritores en Argentina (1970-1986). La Plata: Al Margen.

De Marco, Miguel Ángel (2012). “El Consejo Federal de Inversiones. Juan Quilci, su primer presidente y los origines de las propuestas universitarias de integración regional y coordinación del desarrollo". Épocas (5). Devoto, Fernando, Pagano, Nora (2009). Historia de la historiografía argentina. Buenos Aires: Sudamericana. Devoto, Fernando, Pagano, Nora (2004), La historiografía académica y la historiografía militante en Argentina y Uruguay, Buenos Aires: Biblos.

Di Pasquale, Mariano Summo, Marcelo (2015). Las trayectorias intelectuales como problema. En M. Di Pasquale \& M. Summo (coomps.); Trayectorias singulares, voces plurales. Intelectuales en la argentina siglos $X I X-X X$. Buenos Aires: EDUNTREF.

Favaloro, René (2017). ¿Conoce usted a San Martín?. Buenos Aires: Debolsillo.

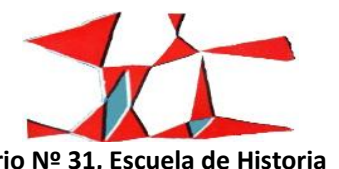

Anuario № 31, Escuela de Historia 


\section{Eugenio Gastiazoro: del MLN al PCR, de la Economía a la Historia (1965-1989)}

Garmendia, Fausto (1979). "El proyecto del '80". Teoría y Política (23).

Garmendia, Fausto (1980). “Librecambio y proteccionismo”. Teoría y Política (26).

Garmendia, Fausto (1981). "Los terratenientes y el imperialismo. Sobre la renta de la tierra". Teoría y Política (29).

Gastiazoro, Eugenio (1970). Critica del Desarrollismo. Buenos Aires: DOS.

Gastiazoro, Eugenio (1971). Desarrollismo o Socialismo. Buenos Aires: Sociales.

Gastiazoro, Eugenio (1972). Argentina hoy: capitalismo dependiente y estructura de clases. Buenos Aires: Polemos.

Gastiazoro, Eugenio (1973). Argentina hoy. Capitalismo dependiente y estructura de clases. Buenos Aires: EMELE.

Gastiazoro, Eugenio (1975). Argentina hoy. Latifundio, dependencia y estructura de clases. Buenos Aires: Pueblo.

Gastiazoro, Eugenio (1976). El problema agrario y sus soluciones. Buenos Aires: Paidos.

Gastiazoro, Eugenio (1978). Léxico de economía. Buenos Aires: CEAL.

Gastiazoro, Eugenio (1980). Historia argentina. Introducción al análisis económico-social (1536-1880). Buenos Aires: Ágora.

Gastiazoro, Eugenio (1986a). Historia argentina. Introducción al análisis económico-social. Tomo I (15151820). Buenos Aires: Ágora.

Gastiazoro, Eugenio (1986b). Historia argentina. Introducción al análisis económico-social. Tomo II (18201880). Buenos Aires: Ágora.

Gastiazoro, Eugenio (1986c). Historia argentina. Introducción al análisis económico-social. Tomo III (18801930). Buenos Aires: Ágora.

Gastiazoro, Eugenio (1986d). “La Revolución del ‘90”. Política y Teoría (10).

Gastiazoro, Eugenio (1987). "Terratenientes, imperialismo y renta agraria”. Política y Teoría (13).

Gastiazoro, Eugenio (1989). “La hegemonía terrateniente en la Revolución de Mayo”. Política y Teoría (16).

Gastiazoro, Eugenio (2004). Historia argentina. Introducción al análisis económico-social. Tomo IV (desde 1930 hasta nuestros días). Buenos Aires: Ágora.

Gastiazoro, Eugenio \& Aramayo, Carlos (1983). “Los terratenientes y el imperialismo”. Política y Teoría (2).

Gastiazoro, Eugenio \& Fiorito, Susana (1965). Ferrocarriles: ¿reestructuración o entrega?. Buenos Aires: MLN.

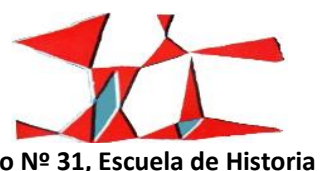

Anuario № 31, Escuela de Historia

Facultad de Humanidades y Artes (Universidad Nacional de Rosario), 2019 ISSN 1853-8835 
MATIAS J. RUBIO

Gastiazoro, Eugenio y Viñas, Ismael (1968). Economía y Dependencia. Buenos Aires: Carlos Pérez Editor.

Gilbert, Isidoro (2009). La FEDE. Alistándose para la revolución. La Federación Juvenil Comunista 1921-2005.

Buenos Aires: Sudamericana.

Gilman, Claudia (2003). Entre la pluma y el fusil. Debates y dilemas del escritor revolucionario en América Latina. Buenos Aires: Siglo XXI.

Grenat, Stella (2011). Una espada sin cabeza. Las FAL y la construcción de un partido revolucionario en los '70. Buenos Aires: RyR.

Irusta, Rosendo (1976). "Sobre el modo de producción dominante en el Virreinato del Rio de la Plata". Teoría y Política (17).

Irusta, Rosendo (1977). "Sobre el modo de producción dominante en el Virreinato del Rio de la Plata $\left(2^{\circ}\right.$ Parte)". Teoría y Política (18).

Laufer, Rodolfo (2018). "Izquierda y clasismo en los 70. Debates frente al Movimiento de Recuperación Sindical - Lista Marrón del SMATA Córdoba". Archivos (12).

Lissandrelo, Guido (2015). “La discusión estratégica en la izquierda argentina en los años '70: Aproximación al debate entre guerrillerismo e insurreccionalismo en el Partido Comunista Revolucionario (PCR), 19671972". Andes (1).

Pacheco, Julieta (2012). Nacional y Popular. EI MALENA y la construcción del programa de liberación nacional (1955-1969). Buenos Aires: ryr.

Páez, Hugo (1975). “Critica a la teoría del capitalismo dependiente”. Teoría y Política (16).

PCR (2005a). Documentos aprobados desde la ruptura con el PC revisionista hasta el $1^{\circ}$ Congreso del PCR. Buenos Aires: PCR.

PCR (2005b). Documentos aprobados por el PCR a partir de su $2^{\circ}$ Congreso, abril de 1972 , hasta su $3^{\circ}$ Congreso, marzo de 1974, Tomo 3. Buenos Aires: Publicaciones $35^{\circ}$ aniversario del PCR.

Rubio, Matias (2017). “Estrategia e inserción del Partido Comunista Revolucionario en el SMATA (19791985)". Archivos (11).

Rubio, Matias (2018a). “El Partido Comunista Revolucionario y la construcción de una interpretación históricopolítica en torno a la cuestión agraria (1967-1987)". Conflicto Social (20).

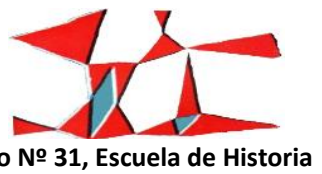

Anuario № 31, Escuela de Historia 


\section{Eugenio Gastiazoro: del MLN al PCR, de la Economía a la Historia (1965-1989)}

Rubio, Matias (2018b). "El Partido Comunista Revolucionario y la aplicación de la teoría del social imperialismo ruso en Argentina (1968-1984)". Ponencia presentada en las II Jornadas de historia del movimiento obrero y la izquierda, CABA, Buenos Aires.

Rubio, Matias (2018c), “El Partido Comunista Revolucionario y la definición de una interpretación histórica en su período formativo (1967-1987). Izquierdas ( $\left.\mathrm{N}^{\circ} 46\right)$.

Rubio, Matías (2017), "El siglo XIX o la formación del capitalismo argentino en la historiografía del Partido Comunista Revolucionario (1968-1987)". Ponencia presentada en las VII Jornadas de la División de Historia En el Centenario de la Revolución Rusa, Universidad Nacional de Luján, Buenos Aires.

Rubio, Matías (2015), “La revolución democrática-nacional, popular, agraria y antiimperialista se inscribe en la historia. Aproximaciones a la historiografía maoísta del Partido Comunista Revolucionario de Argentina". Ponencia presentada en las VI Jornadas de la División Historia - III Taller de Historia Regional, Universidad Nacional de Luján, Buenos Aires.

Rupar, Brenda (2016). "Via pacifica ou via armada: os debates na esquerda revolucionária na década de 1960, através de duas organizações maoístas argentinas". História; (vol. 1).

Rupar, Brenda (2017). "El rol de la revolución cultural china en el maoísmo argentino. Las interpretaciones en las visiones oficiales de Vanguardia Comunista y el Partido Comunista Revolucionario". Leste Vermelho (3). Rupar, Brenda (2018). "El Partido Comunista Revolucionario: de su ruptura con el Partido Comunista Argentino a su adopción del maoísmo (1967-1974)". En Losfeld B. C. y Urrego Ardilla M. Á. (Coord.); La década roja (1966-1976). Morelia: IIH/UMSNH.

Sánchez, Pilar (2008). El gordo Antonio. Vida, pasión y asesinato del dirigente comunista revolucionario Cesar Godoy Álvarez. Buenos Aires: Ágora.

Sarlo, Beatriz (2007). La batalla de las ideas. Buenos Aires, Emecé.

Sigal, Silvia (1991). Intelectuales y poder en la década del sesenta. Buenos Aires: Puntosur.

Simonassi, Silvia (2016). “Debates sobre la industria en Argentina: empresarios, intelectuales y profesionales de Rosario durante la Segunda Guerra Mundial". América Latina en la Historia Económica (2).

Siskindovich, Santiago (2020). "El Partido Comunista Revolucionario y la construcción de la delimitación con el Partido Comunista argentino (1968-1969)". Izquierdas (49).

Vargas, Otto (1985). Sobre el modo de producción dominante en el Virreinato del Rio de la Plata. Buenos Aires: Ágora.

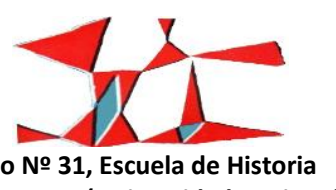


Recibido: 3 de Junio de 2019

Aceptado: 15 de Agosto de 2019

Versión Final: 26 de Septiembre de 2019 